Jurnal Kesehatan Masyarakat

\title{
Utilization of Antenatal Care (ANC) Services by Pregnant Women in Binjai City and Factors Affecting
}

\author{
Herbert Wau, Nidya Razella ${ }^{\bowtie}$ \\ Fakultas Kesehatan Masyarakat, Universitas Prima Indonesia
}

\begin{tabular}{l} 
Article Info \\
\hline Article History: \\
Submitted August 2019 \\
Accepted January 2020 \\
Published March 2020 \\
\hline Keywords: \\
Utilization, Antenatal \\
Care, Pregnant Women \\
\hline DOI \\
https://doi.org/10.15294/ \\
kemas.v15i3.20613
\end{tabular}

\begin{abstract}
Antenatal care services have an influence on fetal growth or during pregnancy, one effort to reduce maternal mortality due to complications is through the use of antenatal care. Based on data from the Health Profile of Kebun Lada Public Health Center, it is known that the scope of ANC services (K1 and K4) in 2017 is K1 96\% AND K4 84\%. In 2018 that is $\mathrm{K} 182.7 \%$ and $\mathrm{K} 481 \%$. Where there is a difference in the percentage of coverage of $\mathrm{K} 1$ and $\mathrm{K} 4$ visits. The research was an analytical survey using Cross Sectional with a sample of 76 people. This research uses chi-square data analysis method with accidental sampling technique to find out the significant influence between, Knowledge, Attitude, ANC Service Facilities, Husband / Family Support and Health Staff Support. This research shows there is influence of Knowledge $(p=0,000)$, Attitude $(p=0,000)$, Service Facilities $(p=0,000)$, Husband / family Support $(\mathrm{p}=0,000)$, Officer Support with $(p=0,001)$ with Utilization of Antenatal Care Services where $p$-value $<0.05$. This study, showed that all factors affect the Antenatal Care service. Health workers, especially midwives, are expected to maintain health education and promotion and motivation on a regular basis about the importance of regular antenatal care.
\end{abstract}

\section{Introduction}

The ability of a country's health services is determined by a ratio of the maternal mortality rate (MMR) and perinatal mortality rate (Tamaka et al., 2013). Maternal Mortality Rate (MMR) is also one indicator that is sensitive to the quality and accessibility of health care facilities (Sari, Nurkamila, \& Mawati, 2018).

WHO estimated that MMR in Indonesia in 2013 reached 190 / 100,000 live births, Southeast Asia has made progress in reducing maternal mortality by $57 \%$. Ten countries reported in $58 \%$ of contributors to maternal mortality in the world in 2013 included Indonesia 3\% (Ulfa et al., 2018). The decline in MMR in Indonesia occurred from 1991 to 2007, from 390 to 228. However, The 2012 IDHS showed a significant increase in MMR to 359 maternal deaths per 100,000 live births.
MMR again showed a decrease to 305 maternal deaths per 100,000 live births based on the 2015 Intercensal Population Survey (SUPAS) (Kementerian Kesehatan Republik Indonesia, 2016)

In the international Millennium Development Goals (MDGs) commitments, the reduction in maternal mortality is one of the eight goals formulated. This commitment is expressed by Indonesia in the direction of Indonesia's long-term health development in 2005-20255 (Erlina, Larasati, \& Kurniawan, 2013). The success of this program will affect the health development program in Indonesia through reducing mortality, especially the Maternal Mortality Rate (MMR) (Sitti Burhaeni, 2013).

One of the health service programs held at the Puskesmas is maternal and child health 
efforts, namely antenatal care (ANC) services (Arwiani et al., 2013). Antenatal care (ANC) is a health service provided by professional health workers for pregnant women, which is carried out regularly and comprehensively (Marniyati et al., 2016). Quality service delivered is estimated to reduce MMR by $20 \%$ and with an effective referral system it can be reduced by 80\% (Maghfirah et al., 2017).

Antenatal care services have an effect on fetal growth or during pregnancy, both with diagnosis and with periodic care for pregnancy complications. The first time pregnant women do antenatal care is a very important time, because various risk factors can be identified as early as possible and can be immediately reduced or eliminated (Nisa et al., 2018). Health services for pregnant women are given through providing antenatal services at least 4 times during pregnancy (Kementerian Kesehatan Republik Indonesia, 2016). The achievement of health services for pregnant women can be assessed using $\mathrm{K} 1$ and $\mathrm{K} 4$ coverage indicators (Khusna, 2016). K1 coverage indicator shows access to health services and the level of compliance of pregnant women in checking their pregnancies to health workers, and $\mathrm{K} 4$ coverage shows the percentage performance of pregnant women receiving ANC services (Fitrayeni et al., 2015).

One effort to prevent maternal mortality is by visiting antenatal services (Jusniany, Mutahar, \& Utama, 2016). The role of pregnant women in utilizing ANC services is affected by individual behavior in the use of health services (Dewi \& Karmaya, 2014). According to Lawrence Green quoted by (Notoatmodjo, 2012), factors affecting the utilization of Antenatal Care services by pregnant women include predisposing factors namely age, education, occupation, knowledge and attitude; enabling factors namely health service facilities, distance and affordability reinforcing factors namely the support of health workers, husband or family

Utilization of ANC services by pregnant women can be seen from the scope of ANC services (K1 and K4). Based on the Health Profile of Kebun Lada, it is known that the scope of ANC services (K1 and K4) in 2017 was 96\% for K1 AND 84\% for K4. In 2018 it was
$82.7 \%$ for $\mathrm{K} 1$ and $81 \%$ for $\mathrm{K} 4$. Where there was a difference in the percentage of coverage of $\mathrm{K} 1$ and $\mathrm{K} 4$ visits, there were cases of maternal mortality in the working area of Puskesmas Kebun Lada where from 2016 to 2017 there were two maternal mortality rates, the cause was due to bleeding, severe anemia, fetal death in the womb, and Preeclampsia. From the causes of maternal mortality, it can be seen that there is a relation between maternal examination that does not check the pregnancy and the maternal mortality.

Based on preliminary surveys conducted by researchers through direct discussions with health workers, there are still pregnant women who do not check their pregnancies regularly. Pregnant women will not get their pregnancy checked again if they are not urged by health workers. Can be seen from the ANC visit data in the past 3 months where in March there were $46(14.7 \%)$ people and in April there were $40(12.8 \%)$ people and in May there were 33 (10.6\%) people so could be concluded that the visit has decreased.

Several previous studies, conducted by (Sriwahyu et al., 2013) on factors related to the use of ANC, stated that of 84 mothers, only 26 mothers used ANC. And it was found there was a correlation between knowledge, health staff support and family/husband support with the use of ANC. Likewise, the results of the study (Farisni, 2017) of 52 pregnant women stated that there was a relation between the attitude of pregnant women, the affordability of health facilities, the support of health workers to the utilization of health services.

Based on the above background, researchers are interested in conducting research on Utilization of Antenatal Care Services (ANC) by Pregnant Women in Binjai City and influencing factors.

\section{Method}

This research is analytic survey type. Analytic survey is a survey or research that tries to explore and why health phenomena occur. Analytic survey here to explain the Utilization of Antenatal Care (ANC) Services by Pregnant Women and the Affecting Factors. This research was conducted at Kebun Lada Health Service Centre (Puskesmas) in Binjai city in 2019. The population in this study were 312 pregnant 
women. The sample size was determined using the Slovin formula so as to produce a sample of 76 people and the sampling technique used was accidental sampling. The data that had been collected would go through the process of editing, codding, and tabulating then it would be analyzed using chi-square to produce univariate and bivariate analysis.

\section{Result and Discussion}

Based on table 1, it shows that of 76 respondents, 25 respondents (33\%) age group ( $<21$ years), 30 respondents (39\%) age group (22-27 years), 14 respondents (18\%) age group (28-32 years) and as many as 7 age group respondents ( $>32$ years). Regarding the education of respondents, it shows that out of 10 respondents (13\%) were SD educated (elementary school), 17 respondents (22\%) were SMP educated (junior high), as much as 47 respondents (62\%) were SMA educated (senior high), and as many as 2 respondents (3\%) were graduate educated (Diploma/Bachelor). Based on the respondents job, it can be seen that 68 respondents $(89 \%)$ were housewives, as many as 8 respondents (11\%) were entrepreneurs, and there is no respondents worked as Private Employees \& Public Servants. Details can be seen in table 1.

Univariate analysis was carried out to determine the frequency distribution of the factors (knowledge, attitudes, antenatal care service facilities (ANC), husband / family support and support of health workers towards pregnant women in the utilization of ANC services at Puskesmas Kebun Lada Binjai in 2019. As seen from table 2.

Based on table 2 for the distribution of categories regarding knowledge obtained from 76 respondents, 58 respondents $(76.3 \%)$ had good knowledge, 14 respondents (18.4\%) had less knowledge and 4 respondents (5.3\%) have poor knowledge. Regarding the attitudes of 76 respondents, as many as 49 respondents (64.5\%) have a good attitude, as many as 25 respondents $(32.9 \%)$ have a less attitude and as many as 2 respondents $(2.6 \%)$ have poor attitude. For ANC service facilities, it shows that of 76 respondents, 57 respondents $(75 \%)$

Table 1. Distribution of Respondents Characteristic Based on Age, Education \& Profession

\begin{tabular}{llll}
\hline No & Characteristic & N & Prrcentage $\%$ \\
\hline $1 . \quad$ Age & 25 & 33 \\
$<21$ & 30 & 39 \\
$22-27$ & 14 & 18 \\
$28-32$ & 7 & 9 \\
$>32$ & 76 & 100 \\
Total & & \\
Education & 10 & 13 \\
SD & 17 & 22 \\
SMP & 47 & 62 \\
SMA & 2 & 3 \\
DIPLOMA/BACHELOR & 76 & 100 \\
Total & & \\
Profession & 68 & 89 \\
House wife & 8 & 11 \\
Enterpreneur & 0 & 0 \\
Private Employee & 0 & 0 \\
Publick Servants (PNS) & 76 & 100 \\
Total & &
\end{tabular}

Source: Primary Data 2019 
Tabel 2. Frequence Distribution of Knowledge, Attitude, ANC Service Facility, Husband/Family Support, Health Worker Support and ANC Service Utilization

\begin{tabular}{|c|c|c|c|}
\hline No & Variable & $\mathbf{N}$ & $\%$ \\
\hline \multirow[t]{5}{*}{1} & Knowledge & & \\
\hline & Poor & 4 & 5,3 \\
\hline & Less & 14 & 18,4 \\
\hline & Good & 58 & 76,3 \\
\hline & Number & 76 & 100 \\
\hline \multirow[t]{5}{*}{2} & Attitude & & \\
\hline & Poor & 2 & 2,6 \\
\hline & Less & 25 & 32,9 \\
\hline & Good & 49 & 64,5 \\
\hline & Number & 76 & 100 \\
\hline \multirow[t]{5}{*}{3} & ANC Service Facility & & \\
\hline & Poor & 1 & 1,3 \\
\hline & Less & 18 & 23,7 \\
\hline & Good & 57 & 75 \\
\hline & Number & 76 & 100 \\
\hline \multirow[t]{5}{*}{4} & Husband/Family Support & & \\
\hline & Not support & 4 & 5,3 \\
\hline & Less support & 13 & 17,1 \\
\hline & Support & 59 & 77,6 \\
\hline & Numbers & 76 & 100 \\
\hline \multirow[t]{4}{*}{5} & Health Worker support & & \\
\hline & Less support & 37 & 48,7 \\
\hline & Support & 39 & 51,3 \\
\hline & Number & 76 & 100 \\
\hline \multirow[t]{4}{*}{6} & ANC Service Utilization & & \\
\hline & Less Utilize & 9 & 11,8 \\
\hline & Utilize & 67 & 88,2 \\
\hline & Number & 76 & 100 \\
\hline
\end{tabular}

Source: Primary data 2019

got good facilities, 18 respondents $(23.7 \%)$ got less facilities and 1 respondent (1.3\%) got poor facilities. Can also be seen from the results of this test with the category of husband / family support obtained from 76 respondents, 59 respondents $(77.6 \%)$ were supported, 13 respondents $(17.1 \%)$ were less supported and 4 respondents $(5.3 \%)$ were not supported. From the category of health workers support obtained from 76 respondents, 39 respondents (51.3\%) were supported and 37 respondents
(48.7\%) were less supported. Based on the results of this statistical test can be seen that the distribution of Utilization of ANC Services obtained from 76 respondents was as many as 67 respondents ( $88.2 \%)$ used them and as many as 9 respondents (11.8\%) less used the ANC Services.

This bivariate analysis is to see whether there is a relation between the independent variables (knowledge, attitude, ANC service facilities, husband / family support, health 
worker support) for pregnant women in the use of antenatal care services using the Chi Square test at the significance level $\alpha=0.05$, as follows: Based on table 3 an analysis of the effect of respondents' knowledge with the use of antenatal care services was obtained from 58 respondents who were well knowledged, there were 55 respondents used antenatal care services and there were 3 respondents who less used. Of 14 respondents who had less knowledge, 11 respondents used antenatal care services and 3 respondents less used. While of 4 respondents who had poor knowledge, 1 respondent used anternatal care services, and 3 respondents less used.

Table 3 also shows the relation between the attitude of respondents with the use of antenatal care services obtained from 49 respondents who had good attitude, there were 47 respondents who used antenatal care services and there were 2 respondents who less use antenatal care services. Of 25 respondents who had less attitude, there were 20 respondents who used antenatal care services and 5 respondents who less use. While of 2 respondents who had poor attitude, both respondents less used antenatal care services.

Based on table 3 regarding the effect of

Table 3. Relation of knowledge, Attitude, ANC Service Fasilities, Husband/Family Support and Health Worker Support to ANC Services Utilization

\begin{tabular}{|c|c|c|c|c|c|c|c|c|}
\hline \multirow{3}{*}{ No } & \multirow{3}{*}{ Variable } & \multicolumn{4}{|c|}{ ANC Services Utilization } & \multirow{2}{*}{\multicolumn{2}{|c|}{ Total }} & \multirow{3}{*}{ P Value } \\
\hline & & \multicolumn{2}{|c|}{ Less Use } & \multicolumn{2}{|c|}{ Use } & & & \\
\hline & & f & $\%$ & f & $\%$ & $\mathbf{f}$ & $\%$ & \\
\hline \multirow[t]{5}{*}{1} & Knowledge & & & & & & & \multirow{5}{*}{0.000} \\
\hline & Poor & 3 & 3.90 & 1 & 1.30 & 4 & 5.20 & \\
\hline & Less & 3 & 3.90 & 11 & 14.50 & 14 & 18.40 & \\
\hline & Good & 3 & 3.90 & 55 & 72.40 & 58 & 76.30 & \\
\hline & Total & 9 & 11.80 & 67 & 88.20 & 76 & 100 & \\
\hline \multirow[t]{5}{*}{2} & Attitude & & & & & & & \multirow{5}{*}{0.000} \\
\hline & Poor & 2 & 2.60 & 0 & 0.00 & 2 & 2.60 & \\
\hline & Less & 5 & 6.60 & 20 & 26.30 & 25 & 32.90 & \\
\hline & Good & 2 & 2.60 & 47 & 61.80 & 49 & 64.40 & \\
\hline & Total & 9 & 11.80 & 67 & 88.10 & 76 & 100 & \\
\hline \multirow[t]{5}{*}{3} & Service Facility & & & & & & & \multirow{5}{*}{0.000} \\
\hline & Poor & 1 & 1.30 & 0 & 0.00 & 1 & 1.30 & \\
\hline & Less & 8 & 10.50 & 10 & 13.20 & 18 & 23.70 & \\
\hline & Good & 0 & 0.00 & 57 & 75.00 & 57 & 75.00 & \\
\hline & Total & 9 & 11.80 & 67 & 88.20 & 76 & 100 & \\
\hline \multirow[t]{5}{*}{4} & Husband/Family Support & & & & & & & \multirow{5}{*}{0.000} \\
\hline & Not support & 3 & 3.90 & 1 & 1.30 & 4 & 5.20 & \\
\hline & Less Support & 3 & 3.90 & 10 & 13.20 & 13 & 17.10 & \\
\hline & Support & 3 & 3.90 & 56 & 73.70 & 59 & 77.60 & \\
\hline & Total & 9 & 11.80 & 67 & 88.20 & 76 & 100 & \\
\hline \multirow[t]{4}{*}{5} & Health Worker Support & & & & & & & \multirow{4}{*}{0.001} \\
\hline & Less Support & 9 & 11.80 & 28 & 36.80 & 37 & 48.70 & \\
\hline & Support & 0 & 0.00 & 39 & 51.30 & 39 & 51.30 & \\
\hline & Total & 9 & 11.80 & 67 & 88.20 & 76 & 100 & \\
\hline
\end{tabular}

Source : Primary data 2019 
service facilities and the utilization of antenatal care services, it is obtained from 57 respondents who had good service facilities, all used antenatal care services and of 18 respondents who had less service facilities, there were 10 respondents who used antenatal care services and there were 8 respondents who did not. While 1 respondent who had poor service facilities mentioned less used anternatal care services.

From Table 3 on the analysis of the effect of respondents' husband / family support to the utilization of antenatal care services, it was obtained that of 59 respondents who were supported, there were 56 respondents who used antenatal care services and 3 respondents who less used. As for 13 respondents who were less supported, 10 respondents still use antenatal care services and 3 respondents less used. Of 4 respondents who were not supported, there was 1 respondent who used anternatal care services, and 3 respondents who less used.

On the effect of support from health worker to the utilization of antenatal care services was obtained from 39 respondents who received support, all used antenatal care services. As for 37 respondents who were less supported, there were 28 respondents who still use antenatal care services and 9 respondents less used antenatal care services.

From the results of the chi-square test on the knowledge variable, the result is $\mathrm{p}=$ 0,000 where the value $(\mathrm{p}<0.05)$ means that $\mathrm{Ho}$ is accepted and $\mathrm{Ha}$ is rejected. Based on the results of the analysis, it means that there is a significant effect between the knowledge of pregnant women and the use of antenatal care services in the working area of Puskesmas Kebun Lada.

The result of this research is in line with research conducted by (Khotimah, Dupai, \& Saktiansyah, 2017) obtained $\mathrm{p}$-value $=0.017$ where there is a significant effect between knowledge and utilization of ANC services. Likewise with research conducted by (Djonis, 2015) that there is a relation between the knowledge of pregnant women with the use of ANC services where the $p$-value $=0,000$ was obtained.

According to Notoatmodjo in (Sumarni, 2014) domain knowledge is very important for the formation of one's actions, in this case a pregnant woman will carry out regular pregnancy checks if the mother knows the benefits of antenatal care for her pregnancy. From the statement by Notoadmodjo this has a very significant relation with behavior, where in this research, maternal behavior highly affects the utilization of antenatal care services, because one indicator of health behavior is knowledge.

In this research, as many as $76.30 \%$ of well-knowledge pregnant women used ANC services. As for less knowledge as much as $18.40 \%$ and poor knowledge as much as $5.20 \%$. There were still pregnant women who did not take advantage of antenatal care because many do not know the pregnancy should be checked referring to a predetermined schedule. The reason was because they did not know the right time schedule to check their pregnancy. A pregnant woman behaves choosing health workers to do a pregnancy check up, determined by how much knowledge about the process and care of the pregnancy itself. This knowledge will bring the mother to think and try to make her healthy / no complaints in her pregnancy and try to keep her and her baby safe and healthy at birth. In this thinking, component of emotions and beliefs are involved, so the mother intends to check her pregnancy. So that mothers have a certain attitude to take advantage of ANC.

From the results of the chi-square test on attitude variables obtained $p=0,000$ where the value ( $\mathrm{p}<0.05$ ), means that Ho is accepted and $\mathrm{Ha}$ is rejected. This means that there is a significant effect of the attitude of pregnant women with the use of antenatal care services in the working area of Puskesmas Kebun Lada.

The results of this study are also in line with research in the puskesmas pegambiran area with the $\mathrm{p}$-value $=0,000$ where there is a significant effect between attitude and utilization of ANC services (Fitrayeni et al., 2015) Likewise with a research conducted by (Dewi \& Karmaya, 2014) mentioned there is a relation between the attitudes of pregnant women with the use of ANC services where a p-value of 0.039 is obtained.

Attitude is one of the psychological factors that can influence consumer behavior, namely in determining a product, brand, and service. (Lailatul, Herawati, \& Witcahyo, 2014). 
In this research it was found that $64.40 \%$ had good attitude. As for those who have less attitudes as much as $32.90 \%$ and poor attitudes as much as $2.60 \%$. There are still mothers who are less utilize the ANC services because the mother will only do a pregnancy check up if there are complaints or illness in her pregnancy if she does not experience complaints the mother will not go for a pregnancy check. Attitude is not a condition that congenitally but is formed based on experience and can change if there are certain terms and conditions that facilitate the change of attitude. In other words, the solution to reduce the number of concerns of pregnant women about the importance of the role of having a good attitude is to inform and provide counseling about good and health pregnancy to pregnant women when they do a pregnancy check.

From the results of the chi-square test on the service facility variable, the result is $\mathrm{p}$ $=0,000$ where the value $(\mathrm{p}<0.05)$ means that $\mathrm{Ho}$ is accepted and $\mathrm{Ha}$ is rejected. It means that there is a significant effect of service facility for pregnant women and the utilization of antenatal care services in the Puskesmas Kebun Lada working area.

The result is in line with (Maghfirah et al., 2017) obtaining p-value $=0.01$ where there is a significant effect of health facilities to the utilization of ANC services

The antenatal care service facilities available at this puskesmas are closely related to mothers decision to utilize ANC services. In this study, $75.00 \%$ of pregnant women made good use of the service facilities. As for those who use less service facilities as much as $23.70 \%$ and utilize poor service facilities as much as $1.30 \%$. Health service facilities have a role in determining the type and level of services to be selected for consumers and the availability of health facilities can influence a person's choice to determine health services as desired. Health facilities can also affect a person's demand for health service utilization. The availability of complete facilities will increase the utilization of health services.

From the results of the chi-square test on the variable husband / family support obtained $\mathrm{p}=0,000$ where the value $(\mathrm{p}<0.05)$, means that $\mathrm{Ho}$ is accepted and $\mathrm{Ha}$ is rejected. It means that there is a significant effect of husband / family support for pregnant women in utilizing antenatal care services in the Puskesmas Kebun Lada working area.

The resultis in line with research conducted by (Carvalho, Suryadhi, \& Wulandari, 2014) saying that there is a significant relation between husband / family support to the use of antenatal care services obtained p-value $=0.015$. Also with research conducted by (Sriwahyu et al., 2013) saying there is a relation between husband / family support to the utilization of ANC services with a $\mathrm{p}$-value $=0.001$.

Husband's support is a psychologically important factor and can encourage pregnant women in making decisions related to actions that support ANC services and efforts made by husband / family in preparing for birth properly (Muhammad, Arulita, Anik, \& Mahalul, 2018) As well as motivating wives to be more utilize antenatal care (ANC) services. In this research, as many as $77.60 \%$ of pregnant women obtained ANC services due to their husband's support. Basically the influence of husband's support is one of the factors that greatly affect the formation of pregnant woman attitude as the influence of others who are considered important in this case including the family. The family has a role as a decision maker in maintaining the health of its members. The husband is someone closest to the wife, the husband is considered to best understand his wife's needs and desires. During pregnancy, a woman experiences both physical and mental changes. The husband should understand this changes and be more patient. One of the roles of the husband in reducing maternal mortality is that the husband can ensure that during the pregnancy the wife has to carry out a pregnancy check according to the recommendations set out in antenatal care.

From the results of the chi-square test for the health workers support variable obtained $p$ $=0.001$ where the value $(p<0.05)$, means that $\mathrm{Ho}$ is accepted and $\mathrm{Ha}$ is rejected. It means that there is a significant effect of the support of health workers to pregnant women to the use of antenatal care services in the Puskesmas Kebun Lada working area.

This result is in line with the research 
conducted by (Farisni, 2017) said that there is a significant relation between health worker support and utilization of antenatal care services with p-value $=0.001$. Research conducted by (Armaya, 2018) said there is a relation between health worker support and the utilization of ANC services with a $p$-value $=0.021$.

Health worker support is an important factor in social support in the form of information support, the subject's feeling that the environment (health worker) provides clear information about matters relating to pregnancy. In this research, it was found as many as $51.30 \%$ who received support from health workers in utilizing ANC services. As for those who were less supported as much as $48.70 \%$. The pregnant women who got less support from health workers because of the information obtained were not given comprehensively but only the needs of mothers. Also information obtained from health worker was not entirely understood optimally. Efforts that must be made by health workers are health promotion programs for pregnant women by holding classes for pregnant women. According to (Notoatmodjo, 2012) the support of health workers is an activity that is shown by community leaders both formal (teachers, village heads, sub-district heads, health workers) and informal (religious leaders and so on) who have influence in the community.

\section{Conclussion}

This research shows that the variables of knowledge, attitude, service facilities, husband / family support, and health worker support have an effect on the utilization of antenatal care services by pregnant women. Health workers, especially midwives, are expected to maintain health education and promotion as well as regular motivation regarding the importance of regular antenatal care so that they can broaden their knowledge and attitudes about the importance of antenatal care. By prioritizing good service facilities for pregnant women.

\section{References}

Armaya, R. (2018). Kepatuhan Ibu Hamil dalam Melakukan Kunjungan Antenatal Care dan Faktor yang Mempengaruhi. Jurnal Ilmu Kesehatan Masyarakat, 7(01), 43-50.

Arwiani, T., Sekarwana, N., \& Kusnadi, D. (2013). Determinants Of Antenatal Care Utilization
At Public Health Center In Bandung City 2013. 1-24.

Carvalho, H. D. F. P., Suryadhi, N. T., \& Wulandari, L. P. L. (2014). Hubungan antara Pendidikan, Pengetahuan, Sikap, Perilaku dan Dukungan Keluarga dengan Kunjungan Antenatal Care (ANC) Ibu Hamil di Kabupaten Ermera Timor Leste, 2013. Public Health and Preventive Medicine Archive, 2, 22-27.

Dewi, M. K., \& Karmaya, I. N. M. (2014). Relationship between Socio-economic Characteristics and Husband Support with Inclusive Antenatal Care ( ANC) at South Denpasar Health Centre III. Public Health and Preventive Medicine Archive, 2(1), 45-51.

Djonis. (2015). Hubungan Pengetahuan Dan Sikap Ibu Hamil Dengan Pemanfaatan Antenatal Care Di Puskesmas Kampung Dalam Pontianak. Jurnal Vokasi Kesehatan, I Nomor 1(6), 23-27.

Erlina, R., Larasati, T., \& Kurniawan, B. (2013). Faktor-Faktor Yang Mempengaruhi Ibu Hamil Terhadap Kunjungan Pemeriksaan Kehamilan Di Puskesmas Rawat Inap Panjang Bandar Lampung. Medical Journal of Lampung University, 2(4), 29-34.

Farisni, T. N. (2017). Determinan pemanfaatan fasilitas kesehatan oleh ibu hamil. Prosiding Seminar Nasional IKAKESMADA, 978-979.

Fitrayeni, Suryati, \& Faranti, R. (2015). Penyebab Rendahnya Kelengkapan Kunjungan Antenatal Care Ibu Hamil Di Wilayah Kerja Puskesmas Pegambiran. Jurnal Kesehatan Masyarakat Andalas, 101-107.

Jusniany, M., Mutahar, R., \& Utama, F. (2016). Determinan Pemanfaatan Pelayanan Antenatal Yang Adekuat Di Indonesia (Analisis Data Sdki 2012). Jurnal Ilmu Kesehatan Masyarakat, 7(3), 174-181.

Kementerian Kesehatan Republik Indonesia. (2016). Profil Kesehatan Indonesia 2016. In Profil Kesehatan Provinsi Bali.

Khotimah, A. R., Dupai, L., \& Saktiansyah, L. O. A. (2017). Faktor yang Mempengaruhi Pemanfaatan Pelayanan Antenatal Care di Wilayah Kerja Puskesmas Mokoau Kecamatan Kamu Kota Kendari Tahun 2016. Jurnal Ilmiah Mahasiswa Kesehatan Masyarakat, 2(8), 1-8.

Khusna, R. (2016). Analysis of Factors Affecting the Utilization of Antenatal Care in Pegandan Public Health Center Semarang City. Public Health Science Department Faculty of Sport Science Semarang State University.

Lailatul, U. M., Herawati, Y. T., \& Witcahyo, E. (2014). Correlated Factors of Antenatal 
Services Utilization by Pregnant Women at Community Health Center of Tempurejo, Jember 2013. E-Jurnal Pustaka Kesehatan, 2(1), 58-65.

Maghfirah, N., Kesehatan, M. P., Studi, P., Masyarakat, K., Kedokteran, F., \& Ilmu, D. A N. (2017). Faktor - Faktor Yang Berhubungan Dengan Rencana Pemanfaatan Pelayanan Persalinan Oleh Pasien Antenatal Care Di Rumah Sakit Muhammadiyah Taman Puring Tahun 2017. Universitas Islam Negeri (UIN) Syarif Hidayatullah.

Marniyati, L., Saleh, I., \& Soebyakto, B. B. (2016). Pelayanan Antenatal Berkualitas dalam Meningkatkan Deteksi Risiko Tinggi pada Ibu Hamil oleh Tenaga Kesehatan di Puskesmas Sako, Sosial, Sei Baung dan Sei Selincah di Kota Palembang. Jurnal Kedokteran Dan Kesehatan, 3(1), 355-362.

Muhammad, A., Arulita, F., Anik, W., \& Mahalul, A. (2018). Precede-Procede Analysis of Prenatal Class Plus Model in the Optimization Education of High Risk Pregnancy. Jurnal Kesehatan Masyarakat, 9(1), 10-19.

Nisa, L., Sandra, C., \& Utami, S. (2018). Factors of Chronic Energy Deficiency Incidence in High-Risk Pregnant Women and Utilization of Antenatal Care in Jelbuk Public Health Center Jember District. Jurnal Administrasi Kesehatan Indonesia, 6(2), 136.

Notoatmodjo, soekidjo. (2012). Promosi Kesehatan dan Prilaku Kesehatan. jakarta: rineka cipta.
Sari, M., Nurkamila, N., \& Mawati, D. (2018). FaktorFaktor Yang Mempengaruhi Kepatuhan Di Puskesmas Cibungbulang Kabupaten Bogor Provinsi Jawa Barat Tahun 2018. PROMOTOR Jurnal Mahasiswa Kesehatan Masyarakat, 1(2).

Sitti Burhaeni. (2013). Determinant Factors Of The Antenatal Service Utilization In Work Area Puskesmas Pampang Panakukang District Makassar City In 2013. 875-876.

Sriwahyu, A., Yusad, Y., \& Mutiara, E. (2013). Faktor Yang Berhubungan Dengan Pemanfaatan Antenatal Care (Anc) Di Wilayah Kerja Puskesmas Kecamatan Lawe Sumur Kabupaten Aceh Tenggara Tahun 2013. Gizi, Kesehatan Reproduksi Dan Epidemiologi, 2(11 April), 1-14. https://doi.org/10.1007/7081

Sumarni. (2014). Hubungan Pengetahuan Dan Sikap Ibu Hamil Terhadap Perilaku Anc. Media Kesehatan Masyarakat Indonesia, 10(4), 200-204.

Tamaka, C., Madianung, A., \& sambeka jolie. (2013). Hubungan Pengetahuan Ibu Hamil Dengan Keteraturan Pemeriksaan Antenatal Care Di Puskesmas Bahu Kecamatan Malalayang Kota Manado. Ejurnal Keperawatan (e-KP) Volume, 1(1), 1-6.

Ulfa, Z. D., Kuswardinah, A., \& Mukarromah, S. B. (2018). Faktor-Faktor Yang Mempengaruhi Pemanfaatan Pelayanan Kesehatan Maternal Secara Berkelanjutan. Public Health Perspective Journal, 2(2), 184-190. 